ISSN 1392-3196 / e-ISSN 2335-8947

Zemdirbyste-Agriculture, vol. 103, No. 4 (2016), p. 411-418

DOI 10.13080/z-a.2016.103.053

\title{
Pretreatment with spermidine and proline reverses inhibitory effects of Phytophthora capsici stress in pepper
}

\author{
Esra KOÇ ${ }^{1}$, Yeliz KAŞKO ARICI ${ }^{2}$, Cemil İ̧LEK ${ }^{3}$ \\ ${ }^{1}$ Ankara University \\ 06100 Ankara, Turkey \\ E-mail: ekoc@science.ankara.edu.tr \\ ${ }^{2}$ Ordu University \\ 52200 Ordu, Turkey \\ ${ }^{3}$ Niğde University \\ 51200 Niğde, Turkey
}

\begin{abstract}
Phytophthora blight (Phytophthora capsici Leon.), which is one of the most important disease factors incurring great economic losses, causes root crown rot. When pepper seedlings were pretreated with $0.1 \mathrm{mM}$ spermidine (spd), $1 \mathrm{mM}$ spd, $0.1 \mathrm{mM}$ spd $+1 \mathrm{mM}$ proline, $0.1 \mathrm{mM}$ spd $+10 \mathrm{mM}$ proline, $1 \mathrm{mM}$ spd $+1 \mathrm{mM}$ proline and $1 \mathrm{mM}$ spd $+10 \mathrm{mM}$ proline and then exposed to $P$. capsici, they improved their tolerance to subsequent $P$. capsici-induced oxidative damage. It was detected that cultivar 'Sirena RZ F1' was resistant to $P$. capsici and it was determined that cultivar 'Sera Demre- 8 ' exhibited sensitive reaction. $P$. capsici stress caused an increase in total phenolic, malondialdehyde (MDA) and hydrogen peroxide $\left(\mathrm{H}_{2} \mathrm{O}_{2}\right)$ levels, as well as peroxidase (POX) and polyphenol oxidase (PPO) activities in leaves of pepper seedlings. Application of exogenous spermidine and spermidine + proline further increased PPO and POX activity, total phenolic amount. On the other hand, these applications in two cultivars and all days decreased the disease severity, necrosis length and MDA and $\mathrm{H}_{2} \mathrm{O}_{2}$ amounts. These data show that antioxidants, especially polyphenol oxidase, peroxidase and total phenolic appear to protect pepper seedlings against stress-related damage. Moreover, spermidine and spermidine + proline have the potential to scavenge directly free radicals and promote the activity of antioxidant enzymes in pepper seedlings under $P$. capsici stress. In addition, it was also identified that especially $0.1 \mathrm{mM} \mathrm{spd}, 1 \mathrm{mM}$ spd and $0.1 \mathrm{mM}$ spd $+1 \mathrm{mM}$ proline applications decreased the colony growth of $P$. capsici and the amount of zoospores. Therefore, we suggest that spermidine and spermidine + proline could play a protective role in protecting the pepper seedlings from $P$. capsici stress.
\end{abstract}

Key words: antioxidants, Capsicum annuum, disease severity, necrosis, tolerance.

\section{Introduction}

Throughout the world, root rot caused by Phytophthora capsici is one of the most economically destructive soil-borne diseases of pepper (Mo et al., 2014). $P$. capsici attacks the roots, stems, leaves, and fruits of the plants. $P$. capsici is also pathogenic on cocoa, pumpkini watermelon, cantaloupe, honeydew melon, cucumber, bean, squash, tomato and eggplant (Kamoun et al., 2015). It gives rise to losses in all of the peppers in the areas in which pepper is grown. $P$. capsici causes significant product losses in Marmara, Aegean, Mediterranean, Black Sea and Southeastern regions in which the pepper production is carried out in Turkey (Rodríguez-Molina et al., 2010).

Currently, no effective management strategies have been developed due to genetic adaptation capability of $P$. capsici. $P$. capsici produces many infectious propagules including oospores, sporangia, zoospores and encysted zoospores. Once $P$. capsici is introduced into an agricultural area dormant inoculum in the form of thickwalled sexual oospores can remain viable for many years (Lewis, Miller, 2014). The studies conducted on pepper have also shown that control with chemical agents including fungicides against the pepper root rot disease is not significantly effective (Garcia et al., 2012). They also have a negative impact on the human health and cause environmental pollution, decrease the quality of the plant and increase the cost of the product. Therefore, the safest one in the struggle against the disease is the use of resistant cultivars in pepper growing.

New strategies and approaches for protecting plants including pepper against disease are to activate their defence mechanism by elicitor molecules. One of these substances is the polyamines. Polyamines are the aliphatic nitrogen (natural organic polycation) compounds found in a wide variety of living organisms including plants and animals with a low molecule weight and a positive charge in physiological $\mathrm{pH}$ (Roychoudhury et al., 2011). Polyamines are effective in the plant adaptation against various environmental stresses: salinity, hyperosmosis, high temperature, low temperature, drought, $\mathrm{pH}$ stress, hypoxia, environmental pollutants (Rangan et al., 2014). The studies conducted 
demonstrated that spermidine (spd) is participating in the regulation of plant responses to diverse abiotic stresses like drought or osmotic stress, salinity, heat and chilling through direct binding to membrane phospholipids, osmotic adjustment, scavenging of free radicals and maintaining a cation-anion balance (Kusano et al., 2008). In vitro studies have shown that proline is a reactive oxygen scavenger and therefore its protective property may have an antioxidant effect (Soshinkova et al., 2013). For this reason, the exogenous polyamine and proline applications are an effective approach which may increase the tolerance to the stress and the product yield. Despite this, the contribution of the polyamine mechanism to the stress in the plant adaptation is still a matter of research. In the last decade, the studies related to the regulation of the plant-polyamine metabolism under growth-related and abiotic stress conditions have become remarkable. The literature reviews we have conducted have shown that the studies are mostly on the abiotic stress. Despite this, there is little information on the plant-polyamine relation in the existence of biotic stress.

For this reason, the aim of this study is to determine the effects of the spermidine and spermidine + proline pre-applications in different concentrations on some physiological parameters such as PPO and POX activity, $\mathrm{MDA}, \mathrm{H}_{2} \mathrm{O}_{2}$ and total phenolic compound levels, disease severity and necrosis length accepted as the most clear disease resistance-response against the pathogen infection in two pepper cultivars having different sensitivities to $P$. capsici. In addition, the direct effects of the applications on the $P$. capsici growth and zoospore amount were investigated. The attained data shall bring new approaches to the control of $P$. capsici and shall open the way for treatment to other species.

\section{Materials and methods}

Plant material. Capsicum annuum L. cultivars 'Sirena RZ F1' and 'Sera Demre-8' were used in the study as plant material. 'Sirena RZ F1' (origin Holland) Grow Fide Production and Marketing Consulting Corporation was supplied from vegetable reclamation research station, pepper cv. 'Sera Demre-8' was supplied from Antalya Agricultural Production and Marketing Consulting Corporation, Turkey. Cultivar 'Sirena RZ F1' is highly productive, charleston-type pepper, tolerant to diseases and cold. It shows early maturity. It is a commercial cultivar for many markets including the Netherlands and Turkey. The fruit of cv. 'Sera Demre- 8 ' is about 15-22 cm long, thin, bright green colour, thick fleshy, smooth cultivar, highly productive, susceptible to disease and is grown commercially in Turkey. The experiment was carried out under growth chamber conditions at University of Ankara, Turkey during the years 2013 and 2014. After germination, pepper seedlings were sown in a plastic pot containing a steam-sterilized soil/fertilizer/sand $\operatorname{mix}(1 / 1 / 1, v / v / v)$. The plants were maintained in a growth chamber under controlled environmental conditions $25 \pm$ $2{ }^{\circ} \mathrm{C}$ and a 16-h light, 8-h dark photoperiod. At the end of the period of approximately two months, the seedlings were collected when they reached the stage of 6 leaves.

The preparation of Phytophthora capsici-22 zoospore suspension. P. capsici-22, obtained from the fungal culture collection of Faculty of Agriculture, Ankara University, Turkey, was grown on V8 agar plates at $25^{\circ} \mathrm{C}$ in the dark (Jones et al., 1975). Zoospores were produced from mycelia. For zoospore production, mycelial plugs were transferred to a flask containing $25 \mathrm{~mL} \mathrm{V8} \mathrm{vegetable}$ juice and incubated in the dark at $25 \pm 2^{\circ} \mathrm{C}$. After $1-2$ weeks, mycelial plugs were removed from the medium and macerated with sterile distilled water in a sterile blender for 30 seconds. Drops of mycelial suspension were placed onto the surface of water-agar plates using a sterile syringe. Sporangial formation in P. capsici-22 was induced by removing uncolonized agar from around the mycelium and incubating the culture for additional 3 days at $25^{\circ} \mathrm{C}$ where plates were placed under fluorescent light (40W daylight) at a distance of $12 \mathrm{~cm}$. Zoospores were induced to release by incubating the culture plates in sterile water at $4^{\circ} \mathrm{C}$ at room temperature for 1 hour. The zoospores were collected and were filtered through Whatman No: 54 to remove sporangial cases and mycelia (Ward, 1976; Koç et al., 2011). Zoospore is a motile asexual spore that uses a flagellum for motion and it is difficult to count, therefore two droplets of lactophenol aniline blue were added to the zoospore suspensions. After the movement of the zoospores which are moving was stopped with the aniline blue with lactophenol of $3 \%$ for spore concentration count, the counting was performed with a hemocytometer (Koç et al., 2011). The concentration was then adjusted to $10^{4}$ zoospores per milliliter and one of the most adequate zoospore concentration causing the disease in the pepper was prepared by dilution with sterile distilled water containing 1-2 drops per L TWEEN ${ }^{\circledR} 20$ (Sigma-Aldrich).

Plant inoculation, spermidine and spermidine + proline applications. The roots of two month-old, uprooted seedlings (leaves) were washed with tap water and disinfected by sodium hypochlorite $(0.75 \%)$ for 1-2 min, before a final rinse. Five washed seedlings were bunched together and wrapped with aluminium foil 3-4 $\mathrm{cm}$ above the root. Each application in each cultivar was repeated three times; three bottles were used for each repetition. Each bottle contained 10 seedlings inside. In other words, a total of 30 seedlings were used for each application and for each single repetition. Ten seedlings were put into a sterile glass bottle containing $400 \mathrm{~mL}$ of Hoagland solution, then the plants were incubated for 3 days at $22 \pm 3^{\circ} \mathrm{C}, 60 \%$ humidity, and 14-h light period, so that they could acclimate. The applications of $0.1 \mathrm{mM}$ and $1 \mathrm{mM}$ spd, spd + proline $(0.1 \mathrm{mM}$ spd $+1 \mathrm{mM}$ proline, $0.1 \mathrm{mM}$ spd $+10 \mathrm{mM}$ proline, $1 \mathrm{mM}$ spd $+1 \mathrm{mM}$ proline and $1 \mathrm{mM}$ spd $+10 \mathrm{mM}$ proline) were performed with the superficial spraying method on the pepper seedlings before the inoculation. The application of distilled water was performed in the control groups. The inoculation procedure was carried out after $72 \mathrm{~h}$ from the application. Three days later, the samples were taken out of seedling bunches from the plant growth chamber, $100 \mathrm{~mL}$ zoospore suspension prepared at $10^{4}$ concentration was put into $250 \mathrm{~mL}$ beakers, and $100 \mathrm{~mL}$ sterile water was added. Then the seedling bunches were dipped into the solutions in the beakers for $1 \mathrm{~h}$, and put into glass bottles again. Bottles were again kept in the same conditions for 3, 5 and 7 days. Under the same conditions, random samples were taken at $3^{\text {rd }}, 5^{\text {th }}$ and $7^{\text {th }}$ days. The leaves were separated and tissues were frozen in liquid nitrogen and ground in a pre-chilled mortar. Afterwards, they were put into nylon bags, labelled and stored at $-70^{\circ} \mathrm{C}$ until the analysis.

Disease evaluation and necrosis length. The reaction test (disease severity and necrosis length) shown by pepper cvs. 'Sirena RZ F1' and 'Sera Demre-8' against $P$. capsici-22 isolate was conducted under the controlled conditions. The plants were incubated for 3 days at $22 \pm 3^{\circ} \mathrm{C}, 60 \%$ humidity, and 14-h light period, so that they could acclimate. The disease severity index value was rated after the pre-application of spd $(0.1 \mathrm{mM}$ and $1 \mathrm{mM})$ and $\mathrm{spd}+$ proline $(0.1 \mathrm{mM} \mathrm{spd}+$ $1 \mathrm{mM}$ proline, $0.1 \mathrm{mM}$ spd $+10 \mathrm{mM}$ proline, $1 \mathrm{mM}$ spd $+1 \mathrm{mM}$ proline and $1 \mathrm{mM}$ spd $+10 \mathrm{mM}$ proline) and 
inoculation based on a 0-5 scale (Kim et al., 1989): $0-$ no visible disease symptoms, 1 - leaves slightly wilted with brownish lesions beginning to appear on stems, 2 - stem lesions extending to cotyledons, defoliated first and second leaves, 3 - stem lesions extending to second leaves, yellowing or defoliation of some upper leaves, 4 - long, brownish lesions on stems extending to $10 \mathrm{~cm}$, all leaves except the uppermost leaf defoliated, seedling tissues collapsing and shoots wilted, 5 - plant dead. After application and inoculation, random samples were taken at $3^{\text {rd }}, 5^{\text {th }}$ and $7^{\text {th }}$ days and average disease severity, the necrosis lengths were determined. The disease severity was calculated according to the formula of $\sum$ (number of plants $\times$ scale value) / total number of plants.

Determination of polyphenol oxidase (PPO: EC 1.10.3.1) activity. PPO activity was determined according to Zheng et al. (2005). The increase in absorbance for 1 minute was recorded in the spectrophotometer at $420 \mathrm{~nm}$.

Determination of peroxidase (POX: EC 1.11.1.7) activity. POX activity was determined according to Lin and Kao (2001). The increase in absorbance for 1 minute (extinction coefficient is $26.6 \mathrm{mM}^{-1} \mathrm{~cm}^{-1}$ ) was recorded in the spectrophotometer at $470 \mathrm{~nm}$.

Analysis of total phenolic compounds. Folin ciocaltaeu method was used in the determination of phenolic compounds (Singleton et al., 1999). Phenolic compound contents were calculated using gallic acid standard and results were recorded as per gram of fresh weight.

Determination of hydrogen peroxide $\left(\mathrm{H}_{2} \mathrm{O}_{2}\right)$ content. Hydrogen peroxide content in pepper leaves was determined in accordance with Velikova et al. (2000). The absorbance of the supernatant was measured at 390 $\mathrm{nm}$. The content of $\mathrm{H}_{2} \mathrm{O}_{2}$ was calculated by comparison with a standard calibration curve previously made by using different concentrations of $\mathrm{H}_{2} \mathrm{O}_{2}$.

Malondialdehyde (MDA) analysis. Malondialdehyde concentration in pepper leaves was calculated according to thiobarbituric acid reaction and MDA content $\left(155 \mathrm{mM}^{-1} \mathrm{~cm}^{-1}\right)$ was calculated using extinction coefficient (Devasagayam et al., 2003).

Statistical analysis. The normal distribution control of the data attained from the study was checked

A

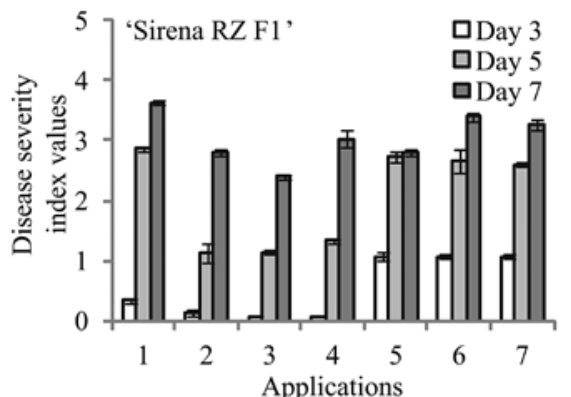

$\mathrm{B}$

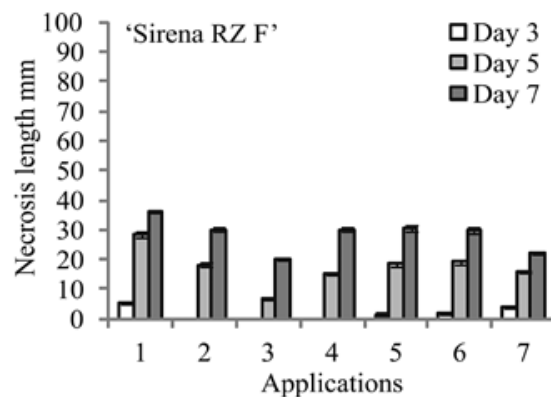

with Anderson-Darling test and the variance homogeneity control of the sub-groups was checked with Levene test. Variance analysis (cultivar $\times$ day $\times$ application) was conducted at the test arrangement in which the data analysis is completely dependent on luck. The trials were organized to create an experimental design with three repetitions in randomized blocks. As a result of analysis of variance, the Tukey test for the determination of different mean values and interpretation of the results at $5 \%$ significance was used. All calculations were made with the use of packaged software Minitab 16. As a result of the variance analyses conducted for all of the properties, the cultivar $\times$ day $\times$ application triple interactions were statistically significant $(p<0.01)$ and in two interactions: application differences in the same cultivar on the same day were found to be statistically significant $(p<$ 0.05 ), differences in cultivars for the same application and same day were found to be statistically significant $(p<0.05)$, differences in days for the same cultivar and same application were found to be statistically significant $(p<0.05)$. Vertical bars represent standard errors $(n=3)$.

\section{Results}

Disease severity index, disease evaluation, necrosis length, Phytophthora capsici colony growth and zoospore amount. In the next days after the application, the disease severity determined according to the index of disease scale values belonging to 15 seedlings (for each repetition) which had been evaluated according to the $0-5$ scale is given in Figure 1 for the $3^{\text {rd }}, 5^{\text {th }}$ and $7^{\text {th }}$ days. As a result of the variance analysis conducted, cultivar $\times$ application $\times$ day interaction of the disease severity index values and necrosis length of the two pepper cultivars were found to be statistically significant $(p<0.01)$.

In the $P$. capsici-22 isolate, two pepper cultivars were compared in terms of severity of infection; in the $3^{\text {rd }}$, $5^{\text {th }}$ and $7^{\text {th }}$ days following infection, the highest level of disease and necrosis length among two pepper cultivars were observed in the cv. 'Sera Demre-8' $(p<0.05)$. All $\mathrm{spd}+P$. capsici and spd + proline $+P$. capsici applications before inoculation decreased disease severity index values
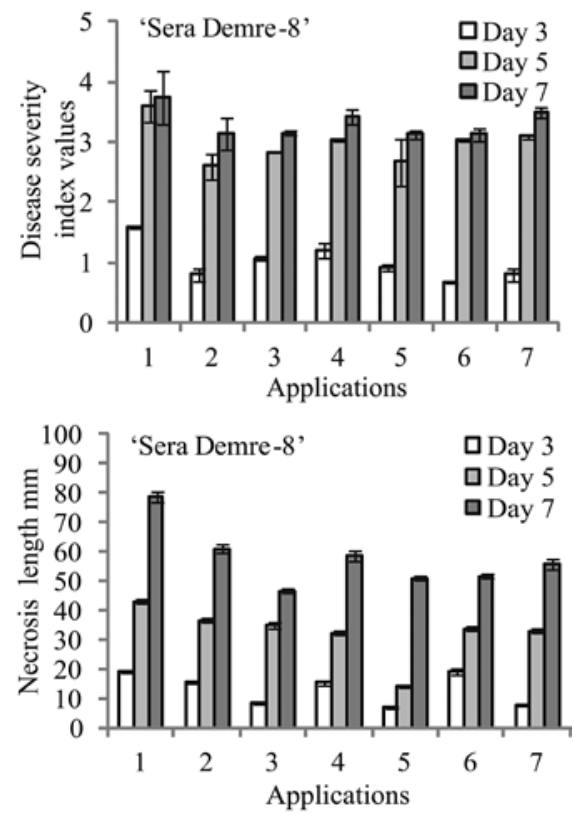

Applications: $1-P$. capsici, $2-0.1 \mathrm{mM}$ spd + P. capsici, $3-1 \mathrm{mM} \mathrm{spd}+P$. capsici, $4-0.1 \mathrm{mM}$ spd $+1 \mathrm{mM}$ proline $+P$. capsici, 5 $-0.1 \mathrm{mM} \mathrm{spd}+10 \mathrm{mM}$ proline $+P$. capsici, $6-1 \mathrm{mM}$ spd $+1 \mathrm{mM}$ proline $+P$. capsici, $7-1 \mathrm{mM}$ spd $+10 \mathrm{mM}$ proline $+P$. capsici

Figure 1. Disease severity index values (A) and necrosis length (B) in pepper seedlings after exposure to Phytophthora capsici alone and spd $+P$. capsici, $\mathrm{spd}+$ proline + P. capsici $(\mathrm{n}=3)(p<0.05)$ 
on $5^{\text {th }}$ and $7^{\text {th }}$ days compared with $P$. capsici in cv. 'Sirena $\mathrm{RZ}$ F1' and $0.1 \mathrm{mM}$ and $1 \mathrm{mM}$ spd were determined as the most effective applications in cv. 'Sirena RZ F1' $(p<0.05)$. All spd $+P$. capsici and spd + proline + P. capsici applications before inoculation decreased disease severity index values in all days compared with $P$. capsici in cv. 'Sera Demre-8' and $0.1 \mathrm{mM}$ spd + P. capsici, $0.1 \mathrm{mM}$ spd $+10 \mathrm{mM}$ proline $+P$. capsici were determined as the most effective applications $(p<0.05)$ (Fig. 1).

All spermidine and spermidine + proline applications before inoculation decreased the necrosis length compared to $P$. capsici alone in two pepper cultivars and difference between them was statistically significant $(p<0.05)$. Thus, $0.1 \mathrm{mM}$ spd $+P$. capsici and $1 \mathrm{mM}$ spd $+P$. capsici were identified as common applications causing decrease in disease severity index values and necrosis length in all days in two pepper cultivars (Fig. 1).

Based on the data, the effect of spm and spm + proline applications on directly $P$. capsici was also determined and the measurement of $P$. capsici colony growth was made. An experiment exposing mycelial plugs to spermidine and spermidine + proline was conducted. For this, P. capsici-22 isolate was grown on V8 agar as previously described at $25 \pm 2^{\circ} \mathrm{C}$ in the darkness. Plugs ( $2 \mathrm{~mm}$ diameter) of mycelium in agar from the edge of a 10-day-old cultures of $P$. capsici were placed in the centre of Petri plates $(9 \mathrm{~cm}$ diameter), previously filled with sterile medium (V8 agar) containing

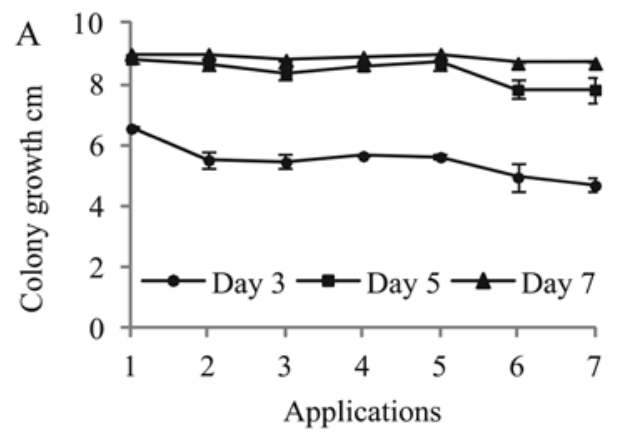

spd $(0.1 \mathrm{mM}$ and $1 \mathrm{mM})$ and $\mathrm{spd}+$ proline $(0.1 \mathrm{mM}$ spd $+1 \mathrm{mM}$ proline, $0.1 \mathrm{mM}$ spd $+10 \mathrm{mM}$ proline, 1 $\mathrm{mM}$ spd $+1 \mathrm{mM}$ proline, $1 \mathrm{mM}$ spd $+10 \mathrm{mM}$ proline), there is no spermidine and spermidine + proline in the control group, then incubated for 7 days at $25 \pm 2^{\circ} \mathrm{C}$ in the darkness and the colony growth of $P$. capsici (colony diameter) was measured on the $3^{\text {rd }}, 5^{\text {th }}$ and $7^{\text {th }}$ days (Fig. 2A). When compared to the control, it was determined that the most effective applications were $0.1 \mathrm{mM} \mathrm{spd}, 1$ $\mathrm{mM}$ spd, $1 \mathrm{mM}$ spd $+1 \mathrm{mM}$ proline and $1 \mathrm{mM}$ spd +10 $\mathrm{mM}$ proline, and these applications decreased the colony growth of $P$. capsici on the $3^{\text {rd }}, 5^{\text {th }}$ and $7^{\text {th }}$ days $(p<0.05)$. We also assayed the effect of spermidine and spermidine + proline on zoospore amount, zoospores were harvested from P. capsici plates (cultivated for 7 days) and incubated with spermidine and spermidine + proline in sterile medium (V8 agar) in Petri plates, the counting was performed with a hemocytometer (Fig. 2B). In this study, it was determined that all the applications decreased the amount of zoospores when compared to the control group (P. capsici), but the most effective applications were 0.1 and $1 \mathrm{mM}$ spd $+P$. capsici, $0.1 \mathrm{mM} \mathrm{spd}+1 \mathrm{mM}$ proline $+P$. capsici $(p<0.05)$.

Polyphenol oxidase (PPO) and peroxidase (POX) activity in the leaves of pepper cultivars. When the PPO activity was compared in the treatment of $10^{4}$ zoospore $\mathrm{ml}^{-1}$ P. capsici in the $3^{\text {rd }}, 5^{\text {th }}$ and $7^{\text {th }}$ days following the infection, the activity difference of cv. 'Sirena RZ F1' among other cultivars was statistically significant $(p<0.05)$. Spermidine and spermidine + proline pre-

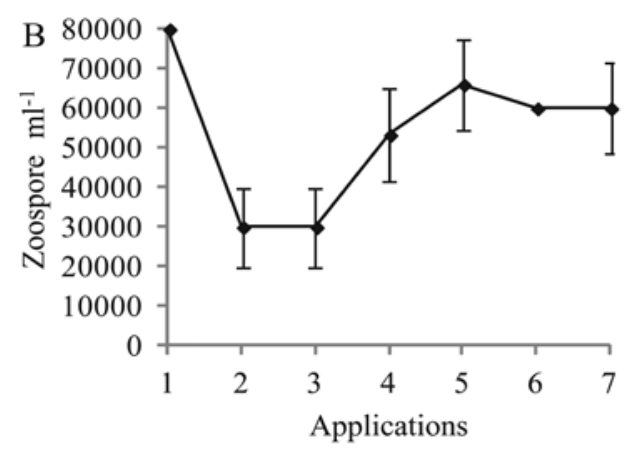

Applications: $1-P$. capsici, $2-0.1 \mathrm{mM} \mathrm{spd}+$ P. capsici, $3-1 \mathrm{mM} \mathrm{spd}+$ P. capsici, $4-0.1 \mathrm{mM} \mathrm{spd}+1 \mathrm{mM}$ proline $+P$. capsici, $5-$ $0.1 \mathrm{mM} \mathrm{spd}+10 \mathrm{mM}$ proline $+P$. capsici, $6-1 \mathrm{mM}$ spd $+1 \mathrm{mM}$ proline $+P$. capsici, $7-1 \mathrm{mM} \mathrm{spd}+10 \mathrm{mM}$ proline $+P$. capsici

Figure 2. Phytophthora capsici colony growth in the $3^{\text {rd }}, 5^{\text {th }}$ and $7^{\text {th }}$ days (A) and zoospore count from the zoospore suspensions formed from the micelle, cultivated for 7 days (B) in the medium supplemented with spermidine, spermidine + proline at $25 \pm 2{ }^{\circ} \mathrm{C}(\mathrm{n}=3)(p<0.05)$

applications before inoculation increased PPO activity compared to $P$. capsici alone in all days in cv. 'Sirena RZF1'; the highest increase was found in the $0.1 \mathrm{mM}$ $\mathrm{spd}+10 \mathrm{mM}$ proline $+P$. capsici in $7^{\text {th }}$ day in cv. 'Sirena RZ F1' and the highest increases were found $0.1 \mathrm{mM}$ spd $+P$. capsici in $5^{\text {th }}$ day, $1 \mathrm{mM}$ spd $+P$. capsici, $0.1 \mathrm{mM}$ spd $+1 \mathrm{mM}$ proline $+P$. capsici, $0.1 \mathrm{mM}$ spd $+10 \mathrm{mM}$ proline $+P$. capsici and $1 \mathrm{mM}$ spd $+1 \mathrm{mM}$ proline $+P$. capsici on $7^{\text {th }}$ day in cv. 'Sera Demre- 8 ' $(p<0.05)$ (Fig. 3).

When compared to the control, POX activity in $P$. capsici infected leaves increased on $5^{\text {th }}$ and $7^{\text {th }}$ days in two pepper cultivars (Fig. 3). Spermidine and spermidine + proline pre-applications before inoculation increased POX activity in all days compared to both the control and $P$. capsici alone in two pepper cultivars; the highest increases were found in the $0.1 \mathrm{mM} \mathrm{spd}+10 \mathrm{mM}$ proline $+P$. capsici and $1 \mathrm{mM} \mathrm{spd}+1 \mathrm{mM}$ proline $+P$. capsici in cvs. 'Sirena RZ F1' and 'Sera Demre-8' on $7^{\text {th }}$ day; the difference was statistically significant $(p<0.05)$.
Total phenolic, $\mathrm{H}_{2} \mathrm{O}_{2}$ and $\mathrm{MDA}$ amount in the leaves of pepper cultivars. When compared to the control, total phenolic in $P$. capsici infected leaves increased in all days throughout the experimental period in two cultivars. All spermidine and spermidine + proline pre-applications before inoculation increased total phenolic amount compared to $P$. capsici alone in two pepper cultivars on the $5^{\text {th }}$ and $7^{\text {th }}$ days; the highest increases were found in the $0.1 \mathrm{mM}$ spd $+10 \mathrm{mM}$ proline $+P$. capsici and $1 \mathrm{mM}$ spd $+10 \mathrm{mM}$ proline $+P$. capsici in cv. 'Sirena RZ F1' and $0.1 \mathrm{mM}$ spd $+P$. capsici and $1 \mathrm{mM}$ spd +10 $\mathrm{mM}$ proline $+P$. capsici in cv. 'Sera Demre- 8 ' on $7^{\text {th }}$ day $(p<0.05)$ (Fig. 4).

An increase was determined in $\mathrm{H}_{2} \mathrm{O}_{2}$ amount compared to the control in all days following the infection in two cultivars $(p<0.05)$ (Fig. 4$)$. When compared to $P$. capsici alone, all spermidine and spermidine + proline pre-applications before inoculation decreased $\mathrm{H}_{2} \mathrm{O}_{2}$ amount in two pepper cultivars; the difference between 
A

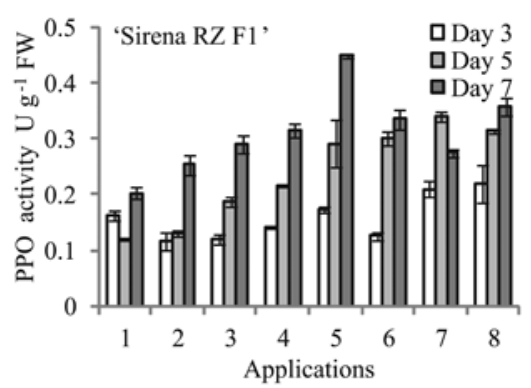

B

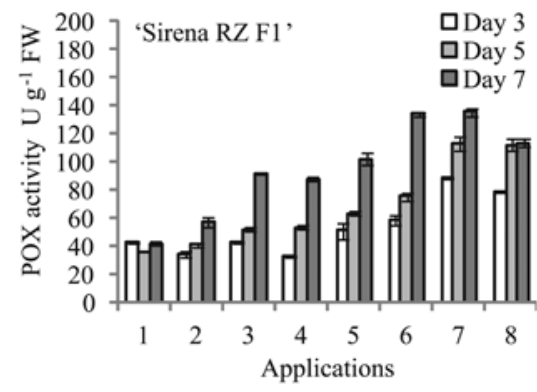

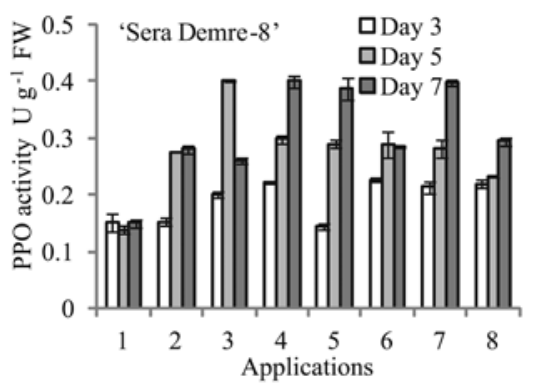

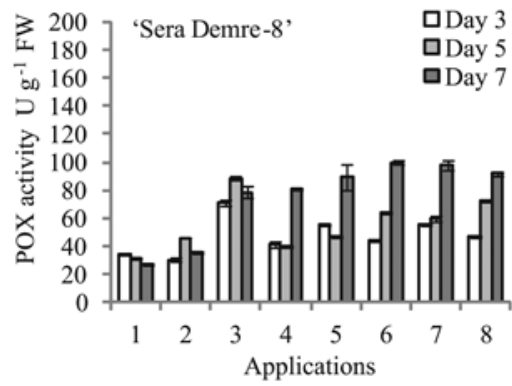

Applications: $1-$ control, $2-$ P. capsici, $3-0.1 \mathrm{mM}$ spd + P. capsici, $4-1 \mathrm{mM} \mathrm{spd}+$ P. capsici, $5-0.1 \mathrm{mM}$ spd $+1 \mathrm{mM}$ proline + P. capsici, $6-0.1 \mathrm{mM}$ spd $+10 \mathrm{mM}$ proline + P. capsici, $7-1 \mathrm{mM} \mathrm{spd}+1 \mathrm{mM}$ proline + P. capsici, $8-1 \mathrm{mM} \mathrm{spd}+10 \mathrm{mM}$ proline + P. capsici

Figure 3. The changes in polyphenol oxidase (PPO) (A) and peroxidase (POX) activity (B) in the leaves of pepper seedlings after exposure to Phytophthora capsici alone and spd $+P$. capsici, $\mathrm{spd}+$ proline $+P$. capsici $(\mathrm{n}=3)(p<0.05)$
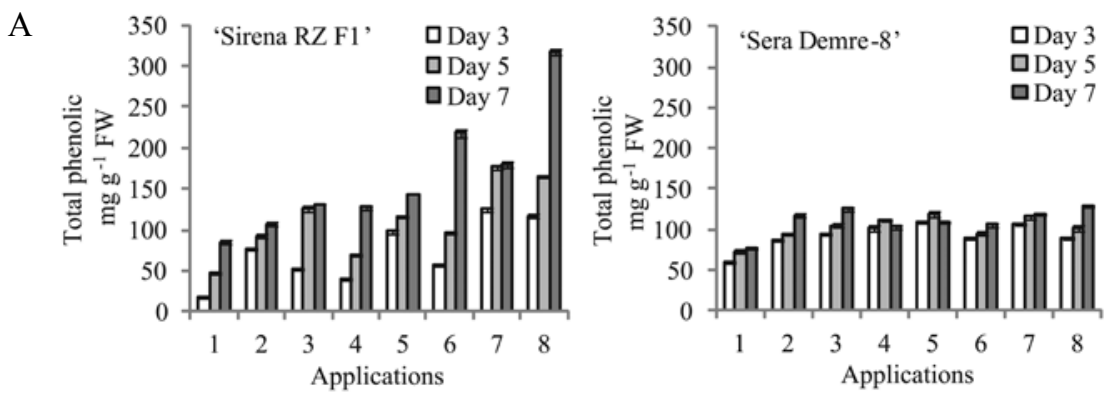

B
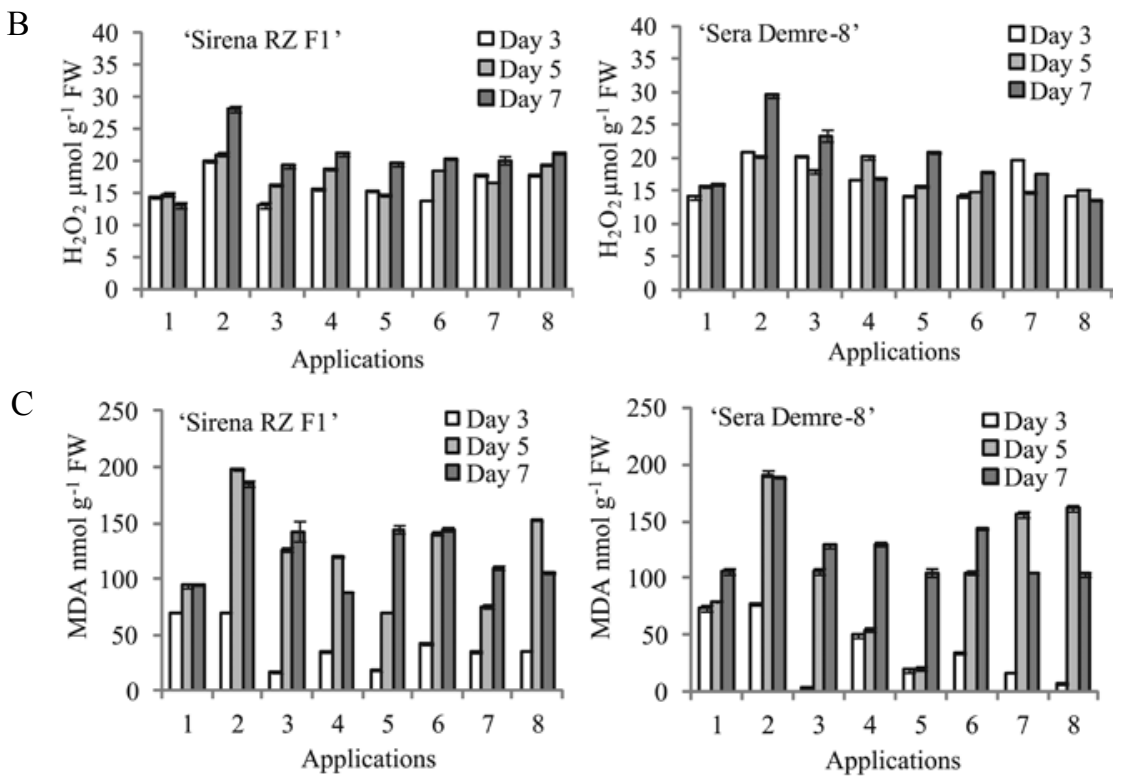

Applications: $1-$ control, $2-$ P. capsici, $3-0.1 \mathrm{mM}$ spd + P. capsici, $4-1 \mathrm{mM} \mathrm{spd}+$ P. capsici, $5-0.1 \mathrm{mM}$ spd $+1 \mathrm{mM}$ proline + P. capsici, $6-0.1 \mathrm{mM}$ spd $+10 \mathrm{mM}$ proline $+P$. capsici, $7-1 \mathrm{mM}$ spd $+1 \mathrm{mM}$ proline $+P$. capsici, $8-1 \mathrm{mM} \mathrm{spd}+10 \mathrm{mM}$ proline + P. capsici

Figure 4. The changes in total phenolic (A), hydrogen peroxide $\left(\mathrm{H}_{2} \mathrm{O}_{2}\right)(\mathrm{B})$ and malondialdehyde (MDA) (C) amount in the leaves of pepper seedlings after exposure to Phytophthora capsici alone and spd $+P$. capsici, spd + proline + P. capsici $(\mathrm{n}=3)(p<0.05)$ 
them was found to be statistically significant, the lowest $\mathrm{H}_{2} \mathrm{O}_{2}$ amount was determined in applications $0.1 \mathrm{mM}$ spd $+P$. capsici on $3^{\text {rd }}$ day in cv. 'Sirena RZ F1'cultivar; $1 \mathrm{mM}$ $\mathrm{spd}+10 \mathrm{mM}$ proline $+P$. capsici in cv. 'Sera Demre- 8 ' on $7^{\text {th }}$ day $(p<0.05)$ (Fig. 4$)$.

When compared to the control, MDA amount in $P$. capsici infected leaves increased throughout the experimental period in two pepper cultivars (Fig. 4). When compared to $P$. capsici alone, all spermidine and spermidine + proline pre-applications before inoculation decreased MDA amount in all days in two pepper cultivars; the difference was found to be statistically significant $(p<0.01)$. The minimum MDA amount was determined in the applications $0.1 \mathrm{mM} \mathrm{spd}+P$. capsici on the $3^{\text {rd }}$ day; $0.1 \mathrm{mM} \mathrm{spd}+1 \mathrm{mM}$ proline $+P$. capsici on the $5^{\text {th }}$ day and $1 \mathrm{mM}$ spd $+1 \mathrm{mM}$ proline $+P$. capsici, $1 \mathrm{mM}$ $\mathrm{spd}+10 \mathrm{mM}$ proline $+P$. capsici on $7^{\text {th }}$ day compared with $P$. capsici in two pepper cultivars $(p<0.05)$.

\section{Discussion}

In the present study, it was detected that cv. 'Sirena RZ F1' was the cultivar having the resistance against $P$. capsici-22. It was determined that cv. 'Sera Demre- 8 ' given sensitive reaction to the pathogen. The disease proceeded so rapidly in cv. 'Sera Demre- 8 ' and most of the seedlings were severely damaged at the $7^{\text {th }}$ day and it was detected that there was an increase in the necrosis lengths. In time, the difference between the cultivars was increased in terms of resistance. When the applications were compared all the days in two cultivars; it was detected that the interactions of spermidine and spermidine + proline were decreased the length of the necrosis. These data show that applications were effective against $P$. capsici and they may alleviate the disease factor under stress conditions.

In the studies performed in the last decade related to the control of fungal plant diseases, polyamine treatments are seen as a new strategy. In the study conducted by Santiago et al. (2012) they have detected that exogenously applied polyamines may inhibit the micelle growth. In this study, all spermidine and spermidine + proline pre-applications decreased the amount of zoospores and the colony growth compared to the control and $0.1 \mathrm{mM}$ spd, $1 \mathrm{mM}$ spd and $0.1 \mathrm{mM}$ spd $+1 \mathrm{mM}$ proline were determined as the most effective applications. In this situation, this effect of the polyamines exogenously applied on the hyphal growth of $P$. capsici shows the probability that the endogenous concentrations of these substances may be a factor limiting growth. Therefore, it is not unreasonable to suggest that control of many plant diseases including the root rot disease caused by $P$. capsici via inhibition of fungal polyamine biosynthesis may provide a useful addition to the crop protection. Putrescine applied in low concentrations stimulates the hyphal growth and optimal concentrations of polyamines inhibit hyphal growth (Dey et al., 2014). Therefore, it seems important to select the appropriate concentrations of the compounds used in the studies of controlling the plant diseases. In this study, the fact that $0.1 \mathrm{mM}$ spd, $1 \mathrm{mM}$ spd, $1 \mathrm{mM}$ spd $+1 \mathrm{mM}$ proline and $1 \mathrm{mM}$ spd $+10 \mathrm{mM}$ proline applications were effective concentrations alleviating the colony growth in $P$. capsici was determined. The same applications further decreased the disease index values and necrosis lengths. These results support that these applications may have decreased the ratio of penetration of pathogen to plant.
Plants develop some defense strategies, but, under some conditions, the degree of the stress may exceed the protective property of the defense system of the plant. Therefore, to be able to solve this problem, researchers are trying to develop some effective application such as polyamines. These applications may increase the tolerance of plants against environmental stress and may promote the plant growth and yield.

In the present work, $P$. capsici stress caused an increase in POX and PPO activities, as well as MDA (lipid peroxidation marker) and $\mathrm{H}_{2} \mathrm{O}_{2}$ levels in leaves of pepper seedlings. All spermidine and spermidine + proline applications before inoculation further increased PPO and POX activities in two pepper cultivars, spermidine + proline combinations were determined as the most effective applications on $7^{\text {th }}$ day in two pepper cultivars (common applications: $0.1 \mathrm{mM} \mathrm{spd}+$ $1 \mathrm{mM}$ proline $+P$. capsici in PPO activity and $0.1 \mathrm{mM}$ $\mathrm{spd}+10 \mathrm{mM}$ proline $+P$. capsici, $1 \mathrm{mM}$ spd $+1 \mathrm{mM}$ proline $+P$. capsici in POX activity). Kubis et al. (2014) reported that exogenous spd differentially affected some antioxidant enzymes, and an increase of POX activity was observed in water-stress cucumber. POX stimulates the formation of the compounds such as lignin and suberin strengthening the cell wall and forming a physical barrier to prevent the spread of the pathogen during the life cycle of the plant. Degradation of plant cell membranes increases the PPO activity. This leads to the oxidation of polyphenols to antimicrobial kinins and lignification in plant cells against pathogenic invasion. PPOs produced by kinins have toxic effect on pathogens (Constabel, Barbehenn, 2008). According to Kuvalekar et al. (2011), the host-pathogen interactions which lead to growth inhibition or distortion of development often lead to an increase in PPO activity. All spermidine and spermidine + proline applications decreased MDA and $\mathrm{H}_{2} \mathrm{O}_{2}$ levels in all days and in two cultivars. Due to its polycationic nature, spermidine was suggested to bind directly to the negatively changed membrane phospholipid headgroups thereby help in stabilizing the membrane. Also, in our study, enhanced antioxidant defense enzymes in spermidine and proline treated peppers decreased $\mathrm{H}_{2} \mathrm{O}_{2}$ and MDA content. Proline and spermidine are reactive oxygen scavengers, as Hossain and Fujita (2010) and Soshinkova et al. (2013) reported, with these protective properties against oxidative damage, the lipid peroxidation levels decrease.

In the present work, $P$. capsici stress caused an increase in total phenolic levels in leaves of pepper seedlings. All spermidine and spermidine + proline preapplications before inoculation further increased total phenolic level in two pepper cultivars. Application of exogenous $1 \mathrm{mM}$ spd $+10 \mathrm{mM}$ proline $+P$. capsici was determined as the most effective application on $7^{\text {th }}$ day in two pepper cultivars. Similarly, in the study conducted by Chunthaburee et al. (2015) they have detected that pre-treatment with spermidine increased phenolic content and antioxidant capacities in rice cultivars in salt stress. Exogenous spermidine may have stimulated the metabolic pathways leading to synthesis of certain groups of phenolic compounds. Proline, proline precursors and proline analogues effectively stimulated total phenolic content and specific phenolic metabolites (Posmyk, Janas, 2007). Phenolics have important roles in defence system of the host plants against fungal invasion. Phenolic compounds may confer resistance to a disease by limiting the growth of the pathogen; help to 
strengthen the cell wall against the pathogens (Kuvalekar et al., 2011). For the purpose of strengthening the cell wall, hydroxy interacts with proline-rich proteins during the penetration of the pathogen. More importantly the antiradical efficiency showed a high positive correlation with total phenolic, suggesting that phenolics are the main compounds responsible for radical-scavenging activity (Shen et al., 2009). Also, with their fungitoxic properties, they change the protoplasmic content and cytoplasmic organization of pathogen by surrounding the hyphae (Vidhyasekaran, 2007). Therefore, quantification of phenolic compounds at progressive disease stages becomes important in recognizing the response of the host plant to the invading pathogen.

These findings show that spermidine serves as the signal molecule stimulating the defense responses and enhanced levels of these defence compounds (PPO, POX and total phenolic) thereby aiding the pepper to increase tolerance to oxidative stress. In other words, spermidine and proline are able to influence oxidative stress intensity through activating some activities of scavenging system enzymes under $P$. capsici stress. Proline function was considered as an osmoprotectant and reactive oxygen scavenger for the detoxification of reactive oxygen species (ROS).

Different cultivars produce different defense reactions - one consequence of underlying genetic variation. However, it was also determined that spermidine and spermidine + proline interactions are the applications increasing the tolerance of the pepper against the stress of $P$. capsici. The findings provided a clue about the role of these applications in defense and they show that the determination of the appropriate concentrations of polyamine and proline to be applied exogenously (modulation) may be an effective tool for providing the protection of the plant cell against various diseases.

\section{Conclusions}

1. Phytophthora capsici stress caused an increase in total phenolic, malondialdehyde (MDA) and hydrogen peroxide $\left(\mathrm{H}_{2} \mathrm{O}_{2}\right)$ levels, as well as peroxidase (POX) and polyphenol oxidase (PPO) activities in pepper cultivars.

2. Application of exogenous spermidine and spermidine + proline before $P$. capsici inoculation further increased the amount of antioxidants. On the other hand, these applications in the two cultivars and all days decreased the disease severity, necrosis length, malondialdehyde and $\mathrm{H}_{2} \mathrm{O}_{2}$ amounts. $0.1 \mathrm{mM}$ spd + $P$. capsici and $1 \mathrm{mM} \mathrm{spd}{ }^{2}+{ }^{2}$. capsici were identified as common applications causing decrease in disease severity index values and necrosis length in all days in the two pepper cultivars $(p<0.05)$.

3. All spermidine and spermidine + proline applications decreased the colony growth of $P$. capsici, the amount of zoospores and the most effective applications were 0.1 and $1 \mathrm{mM} \mathrm{spd}+P$. capsici, $0.1 \mathrm{mM}$ spd $+1 \mathrm{mM}$ proline $+P$. capsici $(p<0.05)$.

4. Spermidine and spermidine + proline applications increased the tolerance of the pepper against $P$. capsici stress.

\section{Acknowledgements}

This study is a part of the project (No. 112T725) financially supported by the Scientific and Technological Research Council of Turkey (TUBITAK).

Received 16052016 Accepted 30082016

\section{References}

Chunthaburee S., Sanitchon J., Pattanagul W., Theerakulpisut P. 2015. Effects of salt stress after late booting stage on yield and antioxidant capacity in pigmented rice grains and alleviation of the salt-induced yield reduction by exogenous spermidine. Plant Production Science, 18 (1): 32-42 http://dx.doi.org/10.1626/pps.18.32

Constabel C. P., Barbehenn R. 2008. Induced plant resistance to herbivory. Schaller A. (ed.). Defensive roles of polyphenol oxidase in plants. p. 253-269

http://dx.doi.org/10.1007/978-1-4020-8182-8

Devasagayam T. P. A., Boloor K. K., Ramasarma T. 2003. Methods for estimating lipid peroxidation: an analysis of merits and demerits. Indian Journal of Biochemistry and Biophysics, 40: 300-308

Dey A., Gupta K., Gupta B. 2014. Plant adaptation to environmental change. Anjam N. A. et al. (eds.). Role of polyamines in plant-pathogen interactions. Kolkata, India, $\mathrm{p}$. 222-243 http://dx.doi.org/10.1079/9781780642734.0222

Garcia A. C., Arispuro H. E., Tellez M. A. M. 2012. Cell metabolism - cell homeostasis ands response. Paula B. (ed.). Oligoglucan elicitor effects during plant oxidative stress. Rijeka, Croatia, p. 1-12 http://dx.doi.org/10.5772/1081

Hossain M. A., Fujita M. 2010. Evidence a role of exogenous glycinebetaine and proline in antioxidant defense and methylgliyoxal detoxification systems in mung bean seedlings under salt stress. Physiology and Molecular Biology of Plants, 16: 19-29

http://dx.doi.org/10.1155/2014/757219

Jones D. R., Unwin C. H., Ward. E. W. B. 1975. Capsidiol induction in pepper fruit during interactions with Phytophthora capsici and Monilinia fructicola. Phytopathology. 65: 1417-1419 http://dx.doi.org/10.1094/Phyto-65-1417

Kamoun S., Furzer O., Jones J. D., Judelson H. S., Ali G. S. Dalio R. J., Roy S. G. 2015. The top 10 oomycete pathogens in molecular plant pathology. Molecular Plant Pathology, 16: 413-414 http://dx.doi.org/10.1111/mpp.12190

Kim Y. J., Hwang B. K., Park K. W. 1989. Expression of agerelated resistance in pepper plants infected with $P$. capsici. Plant Disease, 73: 745-747 http://dx doi.org/10.1094/PD-73-0745

Koç E., Üstün A.S., Iş̧lek C., Arıcı Y. K. 2011. Defence responses in leaves of resistant and susceptible pepper cultivars infected with different inoculum concentrations of Phytophthora capsici Leon. Scientia Horticulturae. 128(4): 434-442 http://dx.doi.org/10.1016/j.scienta.2011.02.008

Kubis J., Wieczorek J. F., Jelonek M. A. 2014. Polyamines induce adaptive responses in water deficit stressed cucumber roots. Journal of Plant Research. 127 (1): 151$158 \mathrm{http}: / / \mathrm{dx}$.doi.org/10.1007/s10265-013-0585-z

Kusano T., Berberich T., Tateda C., Takahashi Y. 2008. Polyamines: essential factors for growth and survival. Planta. 228: 367-381 http://dx.doi.org/10.1007/s00425-008-0772-7

Kuvalekar A., Redkar K., Harsulka A. 2011. Peroxidase and polyphenol oxidase activities in compatible host-pathogen interaction in Jasminum officinale and Uromyces hobsoni: insights into susceptibility of host. New Zealand Journal of Botany 49 (3): 351-359 http://dx.doi.org/10.1080/0028825X.2011.569727

Lewis M. L., Miller S. A. 2014. Use of the vital stain FUN1 indicates viability of Phytophthora capsici propagules and can be used to predict maximum zoospore production. Mvcologia. $106(2): 362-367$ http://dx.doi.org/10.3852/106.2.362

Lin C. C., Kao C. H. 2001. Abscisic acid induced changes in cell wall peroxidase activity and hydrogen peroxide level in roots of rice seedlings. Plant Science. 160 (2): 323-329 http://dx.doi.org/10.1016/S0168-9452(00)00396-4

Mo H., Wai K. P. P., Siddique Y. H., Kim B. S. 2014. New sources of resistance to Phytophthora capsici in Capsicum spp. Horticulture, Environment and Biotechnology, 55 (1): 50-55 
Posmyk M. M., Janas K. M. 2007. Effects of seed hydropriming in presence of exogenous proline on chilling injury limitation in Vigna radiata L. seedlings. Acta Physiologia Plantarum, 29: 509-517

Rangan P., Sunmarini R., Kumar R., Singh R. 2014. Recent advances in polyamine metabolism and abiotic stress tolerance. BioMed Research International, 2014: 1-9 http://dx.doi.org/10.1155/2014/239621

Rodríguez-Molina M. C., Morales-Rodríguez M. C., Palo C., Palo E., Verdejo E., Duarte M. S., Picón-Toro J. 2010. Phytophthora nicotianae, the causal agent of root and crown rot (Tristeza disease) of red pepper in La Vera region (Cáceres, Spain). Spanish Journal of Agricultural Research, 8 (3): 770-774

Roychoudhury A., Supratim B., Sengupta. D. N. 2011. Amelioration of salinity stress by exogenously applied spermidine or spermine in three varieties of indica rice differing in their level of salt tolerance. Journal of Plant Physiology. 168: 317-328 http://dx.doi.org/10.1016/j.jplph.2010.07.009

Santiago L. V., Chavez J. A. C., Ramirez C. G. L., Herrera J. R. 2012. Polyamine metabolism in fungi with emphasis on phvtopathogenic species. Journal of Amino Acids, 1-13 http://dx.doi.org/10.1155/2012/837932

Shen Y., Jin L., Xiao P., Lu Y., Bao J. 2009. Total phenolics, flavonoids, antioxidant capacity in rice grain and their relations to grain color, size and weight. Journal of Cereal Science. 49: 106-111

http://dx.doi.org/10.1016/j.jcs.2008.07.010
Singleton V. L., Orthofer R., Lamuela-Raventos R. M. 1999. Analysis of total phenols and other oxidation substrates and antioxidants by means of Folin-Ciocalteu reagent. Methods in Enzvmologv. 299: 152-178 http://dx.doi.org/10.1016/S0076-6879(99)99017-1

Soshinkova T. V., Radyakina N. L., Korolkova D. V., Nosov A. V. 2013. Proline and functioning of the antioxidant system in Thellungiella salsuginea plants and cultured cells subjected to oxidative stress. Russian Journal of Plant Physiology, 60 (1): $41-54$ http://dx.doi.org/10.1134/S1021443713010093

Velikova V., Yordanov I., Edreva A. 2000. Oxidative stress and some antioxidant systems in acid rain treated bean plants. Protective role of exogenous polyamines. Plant Science, 151: 59-66 http://dx.doi.org/10.1016/S0168-9452(99)00197-1

Vidhyasekaran P. 2007. Fungal pathogenesis in plants and crops: molecular biology and host defense mechanisms. Boca Raton. USA. p. 1-21 http://dx.doi.org/10.1079/9781845936037.0000

Ward E. W. B. 1976. Capsidiol production in pepper leaves in incompatible interactions with fungi. Phytopathology, 66: 175-176 http://dx.doi.org/10.1094/Phyto-66-175

Zheng H. Z., Cui C. L., Zhang Y. T., Dan W., Yu J., Yong K. K. 2005. Active changes of lignification-related enzymes in pepper response to Glomus intraradices and/or Phytophthora capsici. Journal of Zhejiang University. Science B: 6 (8): 778-786 http://dx.doi.org/10.5958/2229-4473.2015.00018.X

ISSN 1392-3196 / e-ISSN 2335-8947

Zemdirbyste-Agriculture, vol. 103, No. 4 (2016), p. 411-418

DOI $10.13080 /$ z-a.2016.103.053

\title{
Veikimas spermidinu ir prolinu mažina slopinamaji Phytophthora capsici streso poveiki paprikų augalams
}

\author{
E. Koç ${ }^{1}$, Y. Kaşko Arici² C. İşlek ${ }^{3}$ \\ ${ }^{1}$ Ankaros universitetas, Turkija \\ ${ }^{2}$ Ordu universitetas, Turkija \\ ${ }^{3}$ Nigde universitetas, Turkija
}

\section{Santrauka}

Phytophthora capsici yra viena svarbiausių ligų, padaranti didelių nuostolių ir sukelianti pašaknio puvinį. Paprikų daigus apdorojus $0,1 \mathrm{mM}$ spermidinu (spd), $1 \mathrm{mM} \mathrm{spd}, 0,1 \mathrm{mM}$ spd $+1 \mathrm{mM}$ prolinu, $0,1 \mathrm{mM} \mathrm{spd}+10 \mathrm{mM}$ prolinu, $1 \mathrm{mM}$ spd $+1 \mathrm{mM}$ prolinu ir $1 \mathrm{mM}$ spd $+10 \mathrm{mM}$ prolinu, padidejo jų atsparumas $P$. capsici sukeltam oksidaciniam pažeidimui. Nustatyta, kad veislè 'Sirena RZ F1' buvo atspari, o veislè 'Sera Demre- 8 ' - jautri $P$. capsici. Dèl P. capsici sukelto streso paprikų daigų lapuose padidejjo bendras fenolių kiekis, malondialdehido (MDA) bei vandenilio peroksido $\left(\mathrm{H}_{2} \mathrm{O}_{2}\right)$ lygis ir peroksidazès bei polifenolio oksidazès aktyvumas. Egzogeninio spermidino ir spermidino + prolino taikymas toliau didino polifenolio oksidazès bei peroksidazès aktyvumą ir bendrą fenolių kiekị.

Kita vertus, visi poveikio variantai, atlikti su abiem veislèms, sumažino ligos intensyvumą, nekrozės ilgị ir MDA bei $\mathrm{H}_{2} \mathrm{O}_{2}$ kiekí. Tyrimo duomenys rodo, kad antioksidantai, ypač polifenolio oksidazès, peroksidazès ir bendras fenolių kiekis, paprikų daigus apsaugojo nuo streso sukeltų pažeidimų. Be to, spermidinas ir spermidinas + prolinas turejjo potencialą imobilizuoti laisvuosius radikalus ir skatinti antioksidacinių fermentų aktyvumą paprikų daiguose esant $P$. capsici stresui. Taip pat nustatyta, kad ypač veikimas $0,1 \mathrm{mM}$ spd, $1 \mathrm{mM}$ spd ir $0,1 \mathrm{mM}$ spd $+1 \mathrm{mM}$ prolinu sumažino $P$. capsici kolonijos augimą ir zoosporų kiekį. Taigi galima teigti, kad spermidinas ir spermidinas + prolinas galètų apsaugoti paprikų daigus nuo $P$. capsici sukelto streso.

Reikšminiai žodžiai: antioksidantai, atsparumas, Capsicum annuum, ligos intensyvumas, nekrozè.

Please use the following format when citing the article:

Koç E., Kaşko Arici Y., İşlek C. Pretreatment with spermidine and proline reverses inhibitory effects of Phytophthora capsici stress in pepper. Zemdirbyste-Agriculture, 103 (4): 411-418 DOI 10.13080/za.2016.103.053 